\title{
PERAN PSAK 109 DALAM PENINGKATAN AKUNTABILITAS DAN TRANSPARANSI PELAPORAN ZAKAT DI INDONESIA
}

\author{
Muji Astuti \\ Sekolah Tinggi Ilmu Manajemen dan Ilmu Komputer ESQ \\ mujiastuti@esqbs.ac.id
}

\begin{abstract}
The growth of zakah, donation/charity increases every year, though still far from zakah potential estimated by various research institutions. The collection and distribution of zakat, donation/charity is accountably reported to the public in the form of financial statements based on the principles of accountability and transparency. Accountability is associated with the fulfillment of the muzaki expectations to gain and enlarge benefits perceived by mustahik. Transparency is manifested in the publication of the financial statements were prepared based on the financial standards and audited by an independent institution. Transparency and accountability in the dimension of Islam not only worldly but also hereafter, be accountable to Allah SWT. The established of PSAK (Statement of Financial Accounting Standards) 109 at the end of 2011 as the accounting standards of the organization of zakah and donation/charity in Indonesia became a binding foundation for preparing financial statements. This paper describes the application of accounting standards on financial statements of zakah institutions to measure the fulfillment of accountability and transparency, by comparing the reports before and after PSAK 109. The results of this study hopefully will give the contribution to the zakat management organizations in completing the public's expectations in the optimization benefits.
\end{abstract}

Keywords: management of zakat in Indonesia, accountability, transparency, accounting standards, the financial statement.

\begin{abstract}
ABSTRAK :Penerimaan dana zakat, infak/sedekah meningkat setiap tahunnya, meskipun masih jauh dari potensi zakat yang diperkirakan oleh berbagai lembaga penelitian. Penerimaan dan penyaluran dana zakat, infak/sedekah dipertanggungjawabkan kepada publik dalam bentuk laporan keuangan berdasarkan prinsip akuntabilitas dan transparansi. Akuntabilitas dikaitkan dengan pemenuhan harapan muzaki terhadap pertambahan dan perluasan manfaat yang dirasakan oleh mustahik. Transparansi diwujudkan dalam publikasi laporan keuangan yang disusun berdasarkan standar keuangan dan diaudit oleh lembaga independen. Transparansi dan akuntabilitas di dalam Islam berdimensi tidak hanya duniawi namun juga $u k h r a w i$, dipertanggungjawabkan kepada Allah SWT. Lahirnya PSAK (pernyataan standar akuntansi keuangan) 109 pada akhir tahun 2011 sebagai standar akuntansi pengelolaan zakat dan infak/sedekah di Indonesia menjadi landasan mengikat dalam penyusunan laporan keuangan. Paper ini menjelaskan penerapan standar akuntansi pada laporan keuangan lembaga amil zakat untuk mengukur terpenuhinya aspek akuntabilitas dan transparansi, dengan membandingkan laporan sebelum dan sesudah PSAK 109. Metode kualitatif deskriptif dan analisis laporan keuangan secara vertikal serta horizontal digunakan untuk melihat komparasi pengeluaran terhadap penerimaan zakat sehingga diperioleh hubungan antara sumber dana dan pemanfaatannya. Tingkat penyaluran yang direpresentasikan dari analisis tersebut mengindikasikan zakat, infak/sedekah, wakaf serta dana lain dikelola dalam bentuk program pemberdayaan dan didistribusikan kepada yang berhak (mustahik). Hasil studi ini diharapkan
\end{abstract}


memberikan kontribusi bagi organisasi pengelola zakat dalam memenuhi harapan publik dalam optimalisasi manfaat.

Kata kunci: pengelolaan zakat di Indonesia, akuntabilitas, transparansi, standar akuntansi, laporan keuangan

\section{PENDAHULUAN}

\subsection{Latar Belakang Permasalahan}

Zakat merupakan ibadah yang berdimensi vertikal dan horizontal. Menunaikan zakat mencerminkan ketundukan kepada Allah SWT sekaligus wujud kepedulian kepada masyarakat/komunitas. Pada masa Rasulullah dan kekhilafahan Islam, zakat memiliki berperan sebagai instrumen ibadah, sosial dan ekonomi yang memiliki peran besar dalam berbagai sektor kehidupan. Peranan badan amil zakat DKI Jakarta (Bazis) yang terbatas pada pengumpulan dan penyaluran zakat mendorong masyarakat menggagas lembaga pengelolaan zakat yang berbasis pada program terintegrasi. Dompet Dhuafa Republika berdiri di awal tahun 1993 sebagai pelopor lembaga amil zakat pertama di Indonesia yang berbasis media. Undang-Undang No 23 tahun 2011 tentang pengelolaan zakat menegaskan organisasi pengelola zakat terdiri dari lembaga amil zakat (LAZ) yang diinisiasi masyarakat dan Badan amil zakat (BAZ) yang didirikan pemerintah pusat maupun daerah. Hingga Maret 2016 kementrian agama mencatat setidaknya terdapat 28 lembaga amil zakat dan badan amil zakat di Indonesia yang dikukuhkan menjadi lembaga penerima zakat.

Kepercayaan donatur dan penerima manfaat akan meningkat bilamana pengelolaan dana zakat dan infak/sedekah didasarkan pada aspek akuntabilitas dan transparansi; penyajian laporan keuangan tepat waktu, kelengkapan informasi dalam detil setiap account, legitimasi laporan oleh kantor akuntan publik serta kemudahan dalam mengakses laporan keuangan. Dalam rangka peningkatan akuntabilitas dan transparansi laporan keuangan disajikan dengan standar akuntansi keuangan yang relevan.

Sebelum standar keuangan zakat ditetapkan, penyusunan laporan keuangan lembaga pengelola zakat menggunakan PSAK 45; standar keuangan untuk organisasi non profit. Sejalan dengan kebutuhan terhadap standar yang lebih sesuai, forum organisasi zakat (FOZ) yang terdiri dari beberapa lembaga amil zakat menggagas sebuah rancangan standar akuntansi untuk lembaga pengelola zakat. Pernyataan Standar Akuntansi Keuangan (PSAK) 109 yang ditetapkan Ikatan Akuntan Indonesia (IAI) pada akhir 2011 dan mulai diaplikasikan tahun 2012 memberikan arahan terkait pengakuan, pengukuran, penyajian dan pengungkapan transaksi zakat dan infak/sedekah.

Rumusan Permasalahan

Penelitianinimenjelaskan tentang pengaruhpenerapan pernyataan standar akuntansi keuangan (PSAK) 109 dalam meningkatkan transparansi dan akuntabilitas lembaga pengelola zakat. Kajian tersebut dipilih mengingat peran strategis organisasi pengelola zakat, sebagai lembaga yang mengoptimalkan pemanfaatan dana publik untuk peningkatan kesejahteraan taraf hidup masyarakat yang berhak (mustahik). Penelitian ini menekankan pada perubahan penyajian laporan keuangan lembaga pengelola zakat pasca PSAK 109 ditetapkan pada awal tahun 2012, dengan rumusan masalah:

1. Bagaimana PSAK 109 berpengaruh terhadap perubahan penyajian laporan keuangan lembaga pengelola zakat?

2. Apakah perubahan penyajian laporan keuangan tersebut 
meningkatkan akuntabilitas dan transaparansi?

Untuk mempersempit permasalahan, ruang lingkup pembahasan penelitian ini dikhususkan pada:

1. Akuntabilitas dan transparansi terbatas pada aspek keuangan.

2. Pembahasan didasarkan pada data keuangan Dompet Dhuafa periode 2011, 2012 dan 2013.

3. Pembahasan dikhususkan pada dana zakat dan infak/sedekah.

4. Komparasi laporan sebelum dan sesudah PSAK 109 diterapkan.

5. Penggunaan analisis keuangan untuk menilai tingkat pemanfaatan dana.

Tujuan dan Manfaat Penulisan

Penelitian ini dilakukan dengan tujuan menilai pertanggungjawaban dan keterbukaan lembaga pengelola zakat dalam penghimpunan dan penyaluran zakat dan infak/sedekah dikaitkan dengan pemenuhan harapan donator (muzaki) dan penerima manfaat (mustahik). Penelitian ini menghasilkan rekomendasi terkait penyajian keuangan dan pertanggungjawaban lembaga pengelola zakat yang bermanfaat bagi lembaga sejenis, masyarakat, pemerintah, akademisi dan stakeholder lainnya.

\section{Tinjauan Pustaka}

\subsection{Definisi Zakat}

Zakat secara bahasa bermakna suci, bersih, berkah, bertambah dan tumbuh, sedangkan menurut istilah berarti mengeluarkan sejumlah harta tertentu. Suci dan bersih ditujukan pada harta dan orang yang membayar zakat (muzaki); penunaian zakat akan membersihkan harta yang diperoleh dari unsur hak orang lain yang masih melekat. Zakat disebut juga shadaqah karena mencerminkan kebenaran (shidiq) seorang hamba dalam beribadah dan taat kepada Allah SWT, serta bermakna penyerahan harta untuk kebajikan. Zakat memiliki fungsi sebagai ibadah individual, sosial dan ekonomi. Zakat dapat menghilangkan sifat kikir, meningkatkan empati dan tali persaudaraan serta mengurangi kesenjangan sosial. Dari sisi ekonomis, zakat meletakkan harta sebagai alat perjuangan agama dan instrumen pemerataan serta peningkatan kesejahteraan masyarakat. Distribusi harta dari muzaki kepada mustahik memungkinkan lapisan masyarakat terbawah memiliki kemampuan untuk memenuhi berbagai kebutuhan, sehingga sektor produksi dan konsumsi berjalan. Kemiskinan sebagai salah satu permasalahan ekonomi secara gradual dapat diatasi secara sistemik.

Perintah zakat sebagai kewajiban diturunkan di Madinah ketika negara dan pemerintahan telah terbentuk. Pada jaman Rasulullah zakat diberlakukan sebagai ibadah bagi para muzaki dan sumber utama keuangan yang mendanai berbagai pengeluaran negara. Pentingnya zakat disejajarkan dengan shalat, hal tersebut tercermin pada masa Abu Bakar Ash-Shidiq yang memerangi orang-orang yang tidak mau membayar zakat. Pada masa Umar bin Khatab zakat memiliki peran yang lebih luas dan bertujuan mengubah mustahik menjadi muzaki, hal tersebut kemudian diteruskan oleh Utsman bin Affan dengan mendirikan gudang baitul maal untuk menghimpun dan menyalurkan zakat.

\subsection{Penghimpunan dan Penyaluran Zakat}

Zakat dibayarkan dengan ketentuan telah mencapai takaran (nishab) dan masuk satu periode (haul). Penghimpunan zakat di Indonesia berasal dari muzaki perorangan dan entitas. Dana zakat yang dihimpun bersumber dari penghasilan (profesi), harta (uang simpanan, emas, perak), perdagangan/usaha, pertanian serta zakat fitrah. Penerimaan infak/sedekah diperoleh dari perorangan maupun perusahaan dalam jumlah yang tidak terbatas. Infak/sedekah dibedakan 
menjadi infak/sedekah tidak terikat, yang penggunaannya sepenuhnya diserahkan kepada pengelolaa tanpa pembatasan oleh donatur, serta infak/sedekah terikat yang dibatasi penggunaannya sesuai dengan maksud dan permintaan donatur. Penyaluran zakat dibatasi sesuai dengan delapan golongan penerima zakat (ashnaf) yang dapat diuraikan sebagai berikut:

Tabel 2.1.

Golongan Penerima Zakat

\begin{tabular}{|c|c|c|}
\hline No. & Asnaf & Definisi \\
\hline 1. & Fakir & $\begin{array}{l}\text { Pendapatan kurang } 50 \% \text { dari had kifayah dan jumlah } \\
\text { tanggungan. }\end{array}$ \\
\hline 2. & Miskin & $\begin{array}{l}\text { Memiliki pendaparan yang melebihi } 50 \% \text { dari jumlah } \\
\text { tanggungan tetapi kurang dari had kifayah. }\end{array}$ \\
\hline 3. & Amil & $\begin{array}{l}\text { Individu dan organisasi yang menghimpun, mengelola dan } \\
\text { membuat program penyaluran zakat. Dana amil digunakan } \\
\text { untuk operasional lembaga zakat sebanyak } 12.5 \% \text { dari total } \\
\text { penerimaan zakat. }\end{array}$ \\
\hline 4. & Mualaf & $\begin{array}{l}\text { Golongan yang baru masuk Islam, memiliki potensi untuk } \\
\text { masuk Islam, non-muslim yang tidak memusuhi Islam. }\end{array}$ \\
\hline 5. & Ar-Riqab & \\
\hline 6. & Al Gharimin & $\begin{array}{l}\text { Pihak yang berhutang untuk kepentingan masyarakat atau } \\
\text { jatuh miskin karena berhutang. }\end{array}$ \\
\hline 7. & Fi sabilillah & $\begin{array}{l}\text { Orang atau organisasi yang melakukan aktivitas kebaikan/amal } \\
\text { shalih untuk menegakkan kebenaran/agama dan peningkatan } \\
\text { kualitas komunitas. }\end{array}$ \\
\hline 8. & Ibnu Sabil & $\begin{array}{l}\text { Musafir dan semua perjalanan yang tidak bertentangan dengan } \\
\text { nilai Islam. }\end{array}$ \\
\hline
\end{tabular}

Sumber: Said.H. Abdullah, Zamzuri F. Zainal, Rasool M. (2016)

Hal tersebut sejalan dengan beberapa golongan yang disebutkan di dalam Al Qur'an:

"Sesungguhnya zakat-zakat itu, hanyalah untuk orang-orang fakir, orang-orang miskin, pengurus-pengurus zakat, para mu'allaf yang dibujuk hatinya, untuk (memerdekakan) budak, orang-orang yang berhutang, untuk jalan Allah dan orang-orang yang sedang dalam dalam perjalanan, sebagai sesuatu ketetapan yang diwajibkan Allah; dan Allah lagi Maha
Mengetahui lagi Maha Bijaksana".(Al Qur'an : 9:60). Bentuk penyaluran zakat dilakukan secara langsung kepada masing-masing golongan atau pemberdayaan komunitas dalam bentuk program ekonomi, kesehatan, pendidikan atau kemanusiaan. Penggunaan dana infak/sedekah lebih fleksibel dan tidak dibatasi dalam bentuk program yang bersinergi dengan dana zakat maupun berdiri sendiri. Zakat dialokasikan dan didistribusikan sesuai tujuan memaksimalisasi manfaat, 
peningkatan kesejahteraan masyarakat dan penanggulangan kemiskinan dalam bentuk program yang tepat sehingga terjadi transformasi sosial menuju kondisi masyarakat yang lebih sejahtera. Model pengelolaan yang dilakukan oleh lembaga amil zakat tercermin dalam variasi program yang menyelaraskan golongan penerima (mustahik) dengan pemenuhan kebutuhan dasar di berbagai sektor kehidupan.

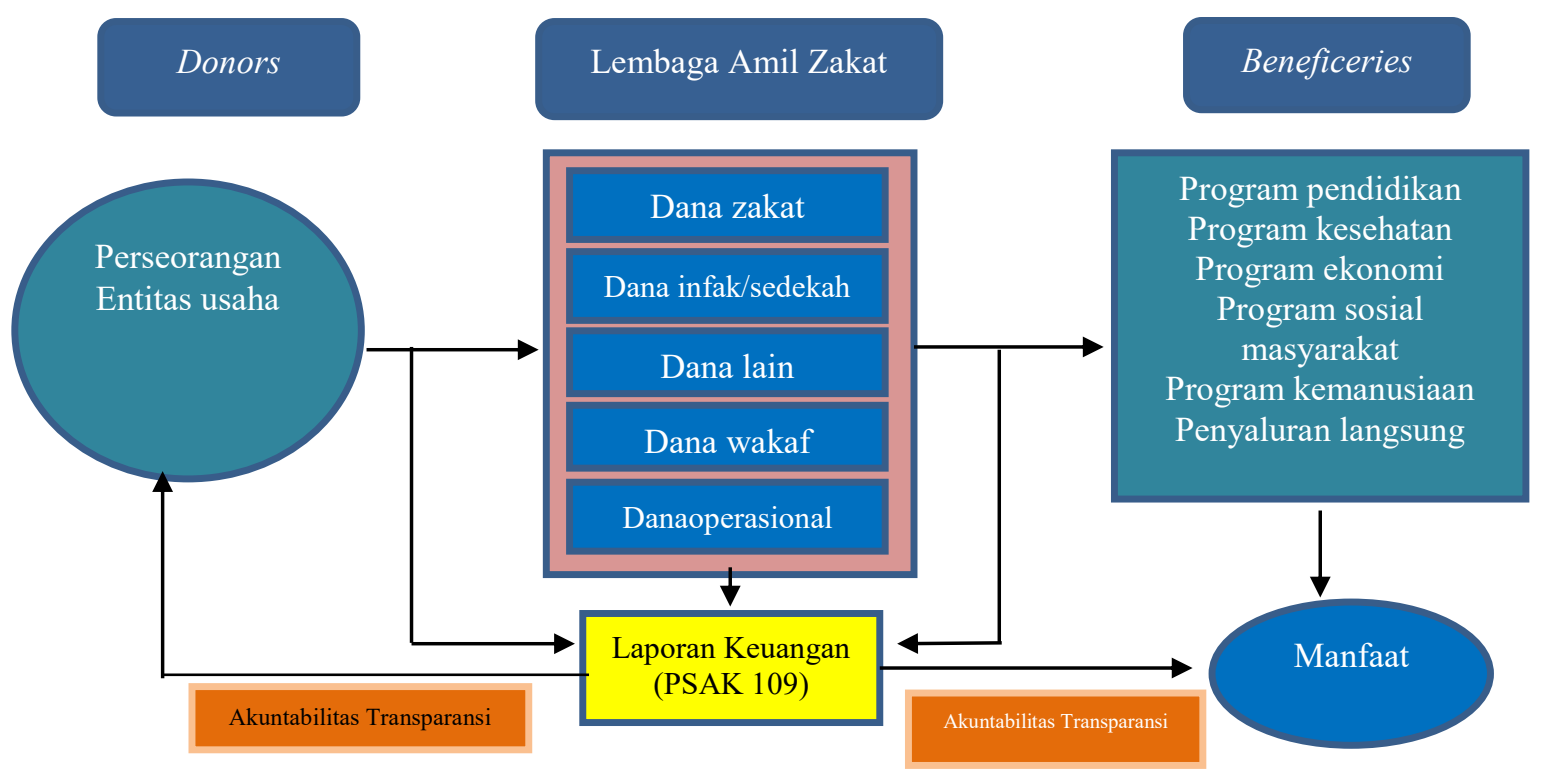

Gambar 2.1. : Skema Pengelolaan dan Pelaporan Zakat Diolah oleh penulis

Program penyaluran langsung bertujuan untuk memenuhi kebutuhan darurat dan mendesak. Pendayagunaan dan pengembangan ekonomi diarahkan untuk meningkatkan pendapatan sehingga mustahik dapat meningkatkan taraf hidup dan kesejahteraan. Program kesehatan berupa layanan kesehatan cuma-cuma menyediakan kesempatan fasilitas pengobatan, perawatan, melahirkan bagi masyarakat kurang mampu. Sekolah tanpa biaya, pelatihan, peningkatan ketrampilan dan pengembangan merupakan beberapa bentuk program pendidikan yang disediakan oleh lembaga pengelola zakat. Program kemanusiaan meliputi penanganan bencana alam mulai dari proses mitigasi hingga recovery. Penyaluran dalam bentuk langsung maupun program bertujuan memaksimalisasi manfaat zakat dan infak/sedekah.

\subsection{Lembaga Pengelola Zakat}

Klasifikasi organisasi pengelola zakat (OPZ) di Indonesia menurut undang-undang zakat No. 23 tahun 2011 terdiri dari Badan Amil Zakat (BAZ) dan Lembaga Amil Zakat (LAZ). BAZ adalah organisasi pengelola zakat yang dibentuk oleh pemerintah yang terdiri dari unsur masyarakat dan pemerintah dengan tugas mengumpulkan, mendistribusikan dan mendayagunakan zakat sesuai dengan ketentuan agama. LAZ merupakan institusi pengelola zakat yang dibentuk oleh masyarakat dan dikukuhkan oleh pemerintah untuk melakukan kegiatan pengumpulan, 
pendistribusian dan pendayagunaan zakat sesuai dengan ketentuan agama. BAZ pertama didirikan oleh pemerintah DKI Jakarta pada tahun 1968 yang diubah menjadi Bazis pada thun 1973. Mencermati pengelolaan zakat oleh Bazis Jakarta yang berkisar pada pengumpulan dan penyaluran zakat, beberapa baitul maal membuat alternativ pengelolaan zakat dalam periode 19801990. Pada tahun 1993 Dompet Dhuafa lahir sebagai LAZ pertama yang berbasis media sekaligus menjadi pelopor penyaluran zakat melalui berbagai program pemberdayaan masyarakat.

Keberadaan amil atau pengelola zakat sangat dibutuhkan mengingat zakat dapat berperan optimal ketika dikelola secara professional. Pemanfaatan zakat untuk kebutuhan konsumtif kurang memberikan dampak besar serta menyebabkan ketergantungan dan terhambatnya transformasi dari mustahik menjadi muzaki. Zakat produktif sesungguhnya bukan merupakan ide baru mengingat Muhammad Arsyad Al Banjari sudah mengemukakan sejak masa penjajahan. Tugas amil menjadi tidak ringan, mengingat program-program yang dirancang harus mencerminkan optimalisasi fungsi dan peran zakat. Undang-undang mengamanatkan bahwa lembaga pengelolaan zakat yang didirikan oleh masyarakat harus melalui proses pengukuhan dan pengesahan oleh pemerintah. Proses tersebut dimaksudkan untuk mendorong tingkat kepercayaan masyarakat dan meningkatkan penerimaan zakat.

\subsection{Regulasi Zakat}

Regulasi tentang pengelolaan dan pengelola zakat pada awalnya dituangkan dalam undang-undang No. 38 tahun 1999 tentang pengelolaan zakat. Undang-undang tersebut lahir dengan dasar pemikiran zakat merupakan salah satu kewajiban umat Islam, sebagai penduduk mayoritas di
Indonesia. Perubahan dilakukan oleh pemerintah dengan ditetapkannya undang-undang No. 23 tahun 2011. Aturan lain terkait zakat termaktub dalam Peraturan Dirjen Pajak No. Per 15/PJ/2012 tanggal 11 Juni 2012 tentang badan atau lembaga penerima sumbangan zakat dan keagamaan sebagai pengurang penghasilan bruto dalam pembayaran pajak. Hingga Oktober 2015 Direktorat Jendral Pajak Kementrian Keuangan mempublikasikan 1 (satu) Badan Amil Zakat Nasional (Baznas), 19 (sembilan belas) lembaga amil zakat dan 2 (dua) badan keagamaan non-Islam yang telah dikukuhkan sebagai penerima zakat dan sumbangan keagamaan.

Undang-undang zakat menempatkan zakat dalam tatanan formal dan hukum nasional, sehingga zakat tidak lagi berada pada ranah tradisional yang dikelola secara parsial tetapi menjadi potensi pendapatan yang harus dikelola secara professional agar mencapai tujuan asasi berupa pemberdayaan masyarakat untuk mencapai kemajuan dan kesejahteraan. Pengaturan zakat dengan sistem hukum yang baku juga memungkinkan zakat terkoneksi dengan aturan pajak dan keuangan. Peraturan berfungsi untuk menggerakan aparatur negara dalam penghimpunan zakat. Regulasi dapat memaksa orang untuk membayar zakat, sehingga potensi zakat yang berdasarkan penelitian baru terkumpul $20 \%$ dapat ditingkatkan secara signifikan.

\subsection{Pelaporan Zakat}

Laporan keuangan merupakan bentuk pertanggungjawaban kepada publik. Sesuai dengan karakter social accounting, tujuan utama pelaporan keuangan lembaga sosial atau non profit adalah dalam rangka pemenuhan aspek transparansi dan akuntabilitas. Akuntabilitas dikaitkan dengan pemenuhan harapan muzaki terkait betambahnya manfaat yang dirasakan oleh mustahik. Transparansi diwujudkan dalam publikasi laporan keuangan yang 
disusun berdasarkan standar keuangan dan diaudit oleh lembaga independen. Tujuan laporan organisasi pengelola zakat (Kustiawan dan Widodo; 2001):

1. Menyajikan informasi bahwa kegiatan OPZ sesuai dengan ketentuan syariah.

2. Menilai pelaksanaan tugas dan tanggung jawab manajemen OPZ.

3. Menilai program dan keberlangsungan kegiatan atau pelayanan OPZ.

Mencermati tujuan tersebut pengelolaan keuangan lembaga amil zakat harus selaras dengan nilai-nilai syariah, untuk itu keberadaan dewan pengawas syariah (DPS) merupakan komponen penting yang memberikan koridor dan menjadi pengawas dalam berbagai program penghimpunan dan penyaluran yang dilakukan. Kebijakan, prosedur dan SOP yang jelas dijadikan dasar bagi aktivitas dan program yang dijalankan. Pengawasan dan evaluasi baik fisik kegiatan, administratif maupun catatan keuangan merupakan mekanisme kontrol yang menjamin kegiatan berjalan sesuai dengan perencanaan dan landasan yang diberikan. Audit internal dan eksternal tidak hanya menilai kinerja dan keuangan namun juga menilai tingkat kepatuhan terhadap aspek syariah.

\subsection{Akuntabilitas dan Transparansi}

Akuntabilitas adalah mempertang gungjawabkan pengelolaan sumber daya serta pelaksanaan kebijakan yang dipercayakan kepada entitas pelaporan dalam mencapai tujuan yang telah ditetapkan secara periodik (KK, SAP,2005). Akuntabilitas merupakan kewajiban menyampaikan pertanggungjawaban atau untuk menjawab atau menerangkan kinerja dan tindakan seseorang/badan hukum/pimpinan kolektif suatu organisasi kepada pihak yang memiliki hak atau berkewenangan untuk minta keterangan akan pertanggungjawaban (LAN, 2003). Dari beberapa definisi tersebut dapat diambil kesimpulan, setidaknya ada tiga kriteria akuntabilitas yaitu; pertanggungjawaban dana publik (dalam bentuk laporan keuangan), penyajian laporan tepat waktu serta adanya pemeriksaan oleh auditor eksternal. Beberapa indikator dapat digunakan untuk menilai akuntabilitas: sistem informasi manajemen dan evaluasi hasil serta akurasi dan kelengkapan informasi. Akuntabilitas di dalam Islam memiliki dimensi vertikal, pertanggungjawaban kepada Allah SWT dan horizontal kepada pihak-pihak terkait (stakeholder). Bentuk pertanggungjawaban pada lembaga pengelola zakat tercermin dalam laporan keuangan yang sesuai dengan Standar Akuntansi yang ditetapkan oleh Ikatan Akuntan Indonesia (IAI).

Transparansi adalah memberika $\mathrm{n}$ informasi keuangan yang terbuka dan jujur kepada masyarakat berdasarkan pertimbangan bahwa masyarakat memiliki hak untuk mengetahui secara terbuka dan menyeluruh atas pertanggungjawaban pemerintah dalam pengelolaan sumber daya yang dipercayakan kepadanya dan ketaatannya pada peraturan perundangundangan (KK, SAP,2005). Peningkatan transparansi memegang peranan penting dalam meningkatkan kepercayaan donatur yang dapat diukur dengan rasio pertumbuhan penerimaan. Kriteria transparansi dapat dilihat dari aspek: adanya pertanggungjawaban dan publikasi laporan keuangan secara terbuka serta kemudahan masyarakat dalam mengakses informasi (laporan) keuangan.

\subsection{Standar Pelaporan Zakat di Indonesia}

Pelaporan keuangan pada awalnya mengacu pada pernyataan standar akuntansi keuangan (PSAK) 45 yang digunakan oleh organisasi non profit dan yayasan. Dalam perkembangannya, forum zakat (FOZ) yang beranggotakan beberapa organisasi pengelola zakat OPZ berusaha merancang standar 
pelaporan yang lebih sesuai dengan karakter pengelolaan zakat, dan pada akhirnya menjadi bahan awal dalam perumusan standar yang definitif bersama ikatan akuntan Indoseia (IAI). Lahirnya PSAK 109 pada akhir tahun 2011 sebagai standar akuntansi pengelolaan zakat dan infak/sedekah di Indonesia menjadi landasan mengikat dalam penyusunan laporan keuangan organisasi pengelola zakat.

PSAK 109 bertujuan untuk mengatur pengakuan, pengukuran, penyajian, dan pengungkapan transaksi zakat dan infak/sedekah (Ikatan Akuntan Indonesia, 2010). Ruang lingkup PSAK 109 adalah organisasi pengelola zakat yang dikukuhkan oleh regulator. Untuk memenuhi aspek transparansi, jenis dana diklasifikasikan setidaknya menjadi:

1. Dana amil, merupakan dana pengelolaan yang berasal dari bagian amil atas dana zakat, infak/sedekah dan dana lainnya.

2. Dana infak/sedekah, merupakan dana yang berasal dari infak/sedekah baik terikat maupun tidak terikat. Infak/sedekah terikat merupakan dana yang peruntukkannya ditentukan oleh muzaki.

3. Dana zakat, merupakan dana yang berasal dari penerimaan zakat.

Pengakuan dan pengukuran penerimaan zakat dan infak/sedekah serta penyaluran zakat dan infak/sedekah diatur di dalam PSAK 109 dengan mempertimbangkan prinsip syariah dan akuntansi. Hal-hal yang perlu diungkap oleh amil menurut PSAK 109 meliputi:

1. Kebijakan penyaluran zakat dan infak/sedekah, seperti penentuan skala prioritas penyaluran dan penerimaan;

2. Kebijakan pembagian antara dana amil dan dana non amil atas penerimaan zakat, seperti persentase pembagian, alasan, dan konsistensi kebijakan;

3. Metode penentuan nilai wajar untuk menentukan penerimaan zakat berupa asset non kas;

4. Rincian jumlah penyaluran dana zakat yang mencakup jumlah beban pengelolaan dan jumlah dana yang diterima langsung mustahiq; dan

5. Hubungan istimewa antara amil dan mustahiq yang meliputi sifat hubungan istimewa, jumlah dan jenis asset yang disalurkan, dan persentase yang disalurkan tersebut dari total penyaluran.

Laporan keuangan sebagi hasil dari siklus akuntansi disajikan setiap periode. Sesuai dengan standar akuntansi yang berlaku penyajian informasi keuangan dalam PSAK 109 dipisahkan menjadi:

1. Laporan posisi keuangan, menggambarkan posisi aset, liabilitas dan saldo dana.

2. Laporan perubahan dana, berisi penerimaan dan penyaluran dana baik zakat, infak/sedekah, non halal maupun dana lain yang didasarkan pada kebijakan lembaga.

3. Laporan perubahan asset kelolaan, menyajikan informasi perubahan aset kelolaan.

4. Laporan arus kas, menjelaskan penambahan dan pengurangan arus kas operasional, investasi dan pendanaan.

5. Catatan atas laporan keuangan, terdiri dari kebijakan, penjelasan dan pernyataan lain terkait perlakuan account atau transaksi.

\subsection{Analisis Laporan Keuangan}

Analisis laporan keuangan dilakukan untuk memahami kinerja organisasi berdasarkan informasi keuangan dan hubungan antar unsur dalam laporan 
keuangan. Analisis laporan keuangan pada umumnya dibedakan menjadi:

1. Analisis horisonal (tren), membandingkan unsur yang sama dalam laporan keuangan pada periode yang berbeda. Teknik ini digunakan untuk mengukur peningkatan kinerja keuangan dari tahun sebelumnya.

2. Analisis vertikal, melihat pengaruh satu komponen dalam laporan keuangan terhadap jumlah totalnya (atau komponen laporan yang dijadikan basis perhitungan). Pada laporan posisi keuangan kas, piutang dan aset lainnya dibandingkan dengan total aset untuk menilai proporsi tiap komponen terhadap total. Pada laporan perubahan dana jenis dana dapat dibandingkan dengan total dana untuk melihat perimbangan dana yang dihimpun. Pengeluaran dana dibandingkan dengan penerimaan untuk mengukur persentase penyaluran dan pemanfaatan dana.

3. Analisis rasio, merupakan komparasi yang menunjukkan hubungan matematis antar unsur dalam laporan untuk tujuan penlaian kinerja yang spesifik.

\subsection{Audit Syariah}

Ruang lingkup regulasi zakat (UU No. 23 tahun 2011) diantaranya mengatur pelaporan dan pertanggungjawaban serta audit syariah lembaga amil zakat. Fungsi audit syariah diantaranya sebagai alat pengawasan dan pengendalian eksternal, mitigasi risiko untuk setiap program dan aktivitas, serta feedback bagi perbaikan lembaga. Menurut Irjen Kementiran Agama (2016) ruang lingkup mitigasi risiko program dan aktivitas lembaga amil zakat:

1. Dana zakat disimpan terlalu lama dan tidak segera disalurkan ke mustahik dengan tujuan mendapatkan keuntungan.

2. Penyaluran tidak sesuai dengan asnaf.

3. Pemanfaatan dana zakat untuk kepentingan pribadi, golongan atau menutup biaya operasional lembaga.

4. Lemahnya sistem control dan tidak adanya SOP yang dipedomani dalam penghimpunan dan penyaluran dana zakat.

5. Tidak adanya pelaporan keuangan sehingga mengabaikan aspek akuntabilitas dan transparansi dalam pengelolaan zakat.

6. Munculnya berbagai permasalahan dalam manajemen seperti lemahnya data base, minimnya pemahaman amil, lambatnya mekanisme keluhan, kurangnya sarana dan prasarana.

\subsection{Dompet Dhuafa}

Inisiatif pendirian Dompet Dhuafa berawal dari penggalangan dana untuk program kepedulian khususnya bagi kegiatan dakwah dan kemanusiaan di Gunung Kidul. Melihat antusiame masyarakat yang cukup tinggi pada 4 September 1994 Dompet Dhuafa didirikan oleh pimpinan harian Republika. Hingga saat ini Dompet Dhuafa memiliki lima kantor cabang serta tiga kantor perwakilan. Pada tahun 2001 Dompet Dhuafa dikukuhkan sebagai Lembaga Amil Zakat tingkat Nasional berdasarkan keputusan Menteri Agama. Hingga saat ini Dompet Dhuafa memiliki 17 cabang di berbagai wilayah Indonesai dan luar negeri serta 9 jejaring aliansi sebagai pelaksana program.

Dalam rangka efektifitas dan efisiensi organisasi serta berjalannya mekanisme kontrol, Dompet Dhuafa melengkapi struktur organisasinya dengan dewan pengurus, dewan 
pembina, dewan pengawas serta dewan penasihat syariah. Penanganan operasional sehari-hari dijalnakan oleh dewan direksi yang terdiri dari presiden direktur, direktur eksekutif, direktur program, direktur keuangan dan umum, direktur pengembangan sosisal serta direktur komunikasi dan pengembangan sumberdaya.

Berbagai program penyaluran zakat dan infak/sedekah dikembangkan oleh Dompet Dhuafa meliputi program kesehatan, pendidikan, ekonomi dan sosial masyarakat. Penjelasan singkat terkait program-pprogram penyaluran Dompet Dhuafa terdapat dalam lampiran
dua.Penerima manfaat pada setiap program ditetapkan melalui serangkaian seleksi untuk memastikan zakat dan infak/sedekah diterima oleh orang yang berhak. Contoh jumlah penerima manfaat untuk program pendidikan terdapat dalam lampiran tiga. Mekanisme penyaluran dana dilakukan berdasarkan kebijakan yang disusun dan diusulkan oleh dewan direksi dalam rencana kerja dan anggaran tahunan, disetujui dan disahkan oleh dewan pengurus, dewan pengawas dan dewan penasihat syariah. Mekanisme penyaluran dana dapat digambarkan sebagai berikut:

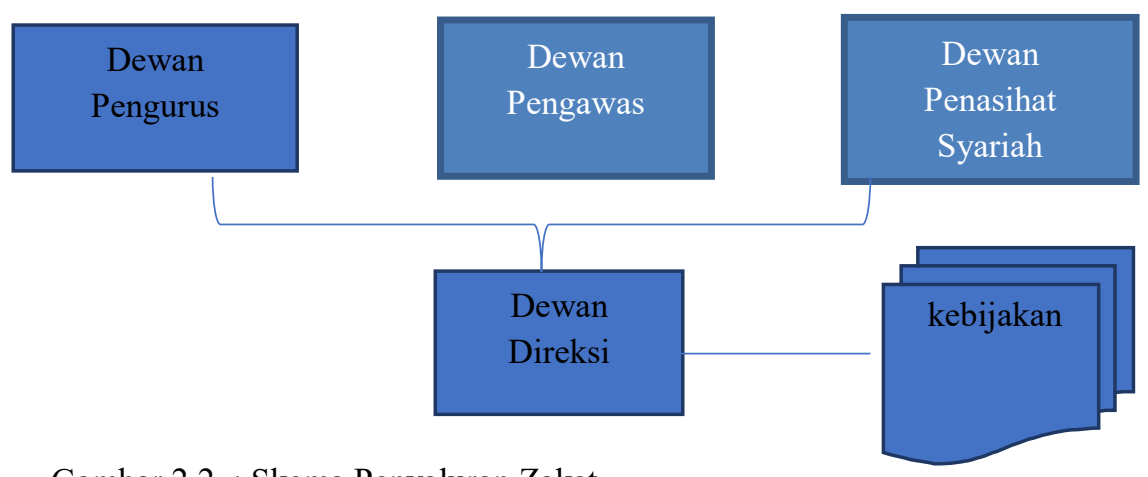

Gambar 2.2. : Skema Penyaluran Zakat

Diolah oleh penulis

\subsection{Metode Penelitian}

\section{METODE PENELITIAN}

\subsection{Data, Waktu dan Tempat Penelitian}

Data yang digunakan dalam penelitian ini adalah data sekunder berupa laporan keuangan Dompet Dhuafa Republika yang telah diaudit. Periode laporan yang digunakan meliputi tahun 2010 hingga 2013 dengan pemikiran sebelum dan sesudah PSAK 109 diterapkan. Data diambil dari laporan posisi keuangan dan laporan perubahan dana khususnya dana zakat dan infak/sedekah.Penelitian dilakukan selama 6 (enam) bulan, bertempat di Jakarta. Karena bersifat analisis dan deskriptif, penelitian lapangan tidak dilaksanakan.
Penelitian ini menggunakan metodologi kualitatif dengan pendekatan analisis laporan keuangan. Penelitian dilakukan terhadap salah satu organisasi pengelola zakat di Indonesia, dengan membandingkan data-data dalam laporan keuangan yang tersaji dalam website yang telah dipublikasikan.

\subsection{Metode Pengolahan Data}

$$
\text { Pengukuran performansi }
$$
keuangan OPZ dilakukan dengan membandingkan pertumbuhan internal dan pengaruhnya terhadap keberhasilan program dalam bentuk analisis vertikal. Analisis horizontal dilakukan untuk melihat peningkatan penerimaan dan penyaluran antar periode. Komparasi laporan keuangan sebelum dan sesudah 
penerapan PSAK 109 diperlukan untuk mendapatkan gambaran pengaruh penerapan PSAK 109 dalam perbaikan pelaporan kepada publik. Metodologi kualitatif dilakukan dengan studi literature yang dipertajam dengan wawancara, studi lapangan dan observasi.

\section{HASIL DAN PEMBAHASAN}

4.1 Pengaruh Penerapan PSAK 109

Pemberlakuan PSAK 109 memiliki implikasi terhadap format penyajian laporan keuangan Dompet Dhuafa. Perubahan tersebut ditegaskan dalam laporan keuangan periode 2011/2012 dalam catatan 19 atas laporan keuangan; yayasan menerapkan Standar Akuntansi Keuangan tertentu dan berlaku tanggal 1 Januari 2012 yang menyebabkan dilakukan reklarifikasi akun atas laporan keuangan untuk tahun yang berakhir 31 Desember 2011 (Yayasan Dompet Dhuafa republika, 2012). Gambaran pengaruh PSAK 109 dalam laporan posisi keuangan terdapat dalam tabel 5.1.

Tabel 41.: Perubahan Format Laporan Posisi Keuangan

\begin{tabular}{|c|c|c|c|}
\hline & 2011 & & 2011 \\
\hline Aset & & Aset & \\
\hline Aset Lancar & & Aset Lancar & \\
\hline Kas dan setara kas & $41,030,111,544.00$ & Kas dan setara kas & $41,030,111,545.00$ \\
\hline Barang berharga & $1,114,199,820.00$ & Piutang & $5,270,612,402.00$ \\
\hline Piutang & $5,270,612,402.00$ & Uang muka kegiatan & $8,329,031,397.00$ \\
\hline $\begin{array}{l}\text { Biaya dibayar } \\
\begin{array}{ll}\text { dan uang } & \text { muka } \\
\text { kegiatan } & \end{array}\end{array}$ & $9,321,880,902.00$ & Biaya dibayar dimuka & $992,849,505.00$ \\
\hline Dana bergulir & $11,210,250,497.00$ & Persediaan & - \\
\hline Investasi & $77,592,292,335.00$ & Barang berharga & $1,114,199,820.00$ \\
\hline Aset Tetap & $50,318,273,376.00$ & Jumlah Aset Lancar & $56,736,804,669.00$ \\
\hline \multirow[t]{5}{*}{ Jumlah aset } & $195,857,620,876.00$ & Aset bukan lancar & \\
\hline & & Dana bergulir & $11,210,250,497.00$ \\
\hline & & Investasi & $77,592,292,335.00$ \\
\hline & & Aset Tetap & $50,318,273,376.00$ \\
\hline & & Jumlah Aset Bukan Lancar & $139,120,816,208.00$ \\
\hline \multirow[t]{2}{*}{$\begin{array}{l}\text { Kewajiban dan saldo } \\
\text { dana }\end{array}$} & & Jumlah aset & $195,857,620,877.00$ \\
\hline & & Liabilitas dan Saldo Dana & \\
\hline Kewajiban modal usaha & $3,625,822,000.00$ & Liabilitas Jangka Pendek & \\
\hline $\begin{array}{l}\text { Biaya masih harus } \\
\text { dibayar }\end{array}$ & $188,048,500.00$ & Utang & $3,625,822,000.00$ \\
\hline Hutang lain-lain & $1,157,402,992.00$ & Biaya masih harus dibayar & $188,048,500.00$ \\
\hline Imbalan pasca kerja & $1,982,392,000.00$ & Utang lain-lain & $1,157,402,992.00$ \\
\hline \multirow[t]{3}{*}{ Jumlah kewajiban } & $6,953,665,492.00$ & Utang pajak & \\
\hline & & Utang jasa giro & $64,172,957.00$ \\
\hline & & Jumlah liabilitas jangka pendek & $5,035,446,449.00$ \\
\hline
\end{tabular}




\begin{tabular}{|c|c|c|c|}
\hline & & Liabilitas jangka panjang & \\
\hline Saldo dana & & Utang & - \\
\hline $\begin{array}{ll}\text { Sumber } & \text { dan } \\
\text { penggunaan dana } & \end{array}$ & $50,019,152,097.00$ & Liabilitas imbalan kerja & $1,982,392,000.00$ \\
\hline Dana termanfaatkan & $138,884,803,287.00$ & Utang lain-lain & - \\
\hline Jumlah saldo dana & $188,903,955,384.00$ & Jumlah liabilitas jangka panjang & $1,982,392,000.00$ \\
\hline \multirow{15}{*}{$\begin{array}{l}\text { Jumlah kewajiban dan } \\
\text { saldo dana }\end{array}$} & $195,857,620,876.00$ & Jumlah liabilitas & $7,017,838,449.00$ \\
\hline & & Saldo dana & \\
\hline & & Terikat permanen & \\
\hline & & Wakaf & $77,203,979,625.00$ \\
\hline & & Terikat peruntukannya & \\
\hline & & Zakat & $42,963,693,598.00$ \\
\hline & & Solidaritas kemanusiaan & $1,828,575,176.00$ \\
\hline & & Zona Madina & $43,723,988,438.00$ \\
\hline & & Tebar Hewan Kurban & $3,246,101,680.00$ \\
\hline & & Infak terikat & $15,765,290,749.00$ \\
\hline & & Tidak terikat peruntukannya & \\
\hline & & Infak & $99,073,958.00$ \\
\hline & & Operasional & $4,009,079,204.00$ \\
\hline & & Jumlah saldo dana & $188,839,782,428.00$ \\
\hline & & Jumlah liabilitas dan saldo dana & $195,857,620,877.00$ \\
\hline
\end{tabular}

Sumber: Laporan Keuangan yayasan Dompet Dhuafa Republika 2012, diolah oleh penulis

Laporan posisi keuangan setelah penerapan PSAK 109 dalam tabel 1 memberikan gambaran account yang lebih lengkap dan terperinci sehingga memudahkan pembaca dan pengguna dalam memahami laporan keuangan. Sesuai dengan standar akuntansi keuangan pelaporan aset dan liabilitas harus memperhatikan likuiditas dan jangka waktu pembayaran, aset diklasifikasikan menjadi aset lancar dan aset tidak lancar, serta liabilitas dipisahkan menjadi liabilitas jangka pendek dan liabilitas jangka panjang. Uang muka kegiatan dan biaya dibayar dimuka memiliki karakter ekonomi dan lingkup aktivitas yang berbeda dan lebih tepat bila pencatatannya dipisahkan.

Klasifikasi yang detil dan sesuai dengan lingkup jenis dana menunjukkan bahwa laporan keuangan memperhatikan aspek keterbukaan (transparansi). Saldo dana yang berasal dari laporan perubahan dana menggambarkan surplus (kelebihan) penerimaan atas penyaluran dana. Dalam PSAK 109 setiap jenis dana dilaporkan secara terpisah, mengingat karakter dana dan penggunanya yang berbeda sebagaimana tergambar dalam tabel 2.1. Penyaluran infak/sedekah lebih fleksibel, oleh karena itu lembaga pengelola zakat membuat variasi program di bidang ekonomi, pendidikan, kesehatan, sosial masyarakat dengan jangkauan penerima yang lebih luas. Perubahan signifikan terjadi dalam laporan perubahan dana zakat, sebagaimana tergambar dalam tabel 4.2. 
Tabel 4.2. : Perubahan Format Laporan Perubahan Dana Zakat

\begin{tabular}{|c|c|c|c|}
\hline \multicolumn{2}{|c|}{ Laporan Sumber dan Penggunaan Dana } & \multicolumn{2}{|c|}{ Laporan Perubahan Dana } \\
\hline Dana Zakat & & Dana Zakat & \\
\hline Penerimaan Zakat & $75,523,980,061.00$ & Penerimaan & \\
\hline Pengembalian Dana Bergulir & $3,392,941,750.00$ & Penerimaan zakat & $75,523,980,061.00$ \\
\hline Penerimaan bagi hasil & $600,163,230.00$ & Penerimaan bagi hasil & $600,163,230.00$ \\
\hline $\begin{array}{l}\text { Pengembalian piutang/penerimaan dana } \\
\text { pembiayaan }\end{array}$ & $758,591,842.00$ & Penerimaan lain-lain & $919,742,058.00$ \\
\hline Penerimaan penjualan aktiva tetap & $129,023,000.00$ & $\begin{array}{l}\text { Jumlah Penerimaan } \\
\text { Dana Zakat }\end{array}$ & $77,043,885,349.00$ \\
\hline Penerimaan lain-lain & $904,021,996.00$ & & \\
\hline Jumlah Penerimaan Dana & $81,308,721,879.00$ & & \\
\hline Penggunaan Dana & & Penyaluran & \\
\hline \multicolumn{4}{|l|}{ Hibah: } \\
\hline Fakir miskin & $38,188,216,801.00$ & Fakir Miskin & $38,188,216,801.00$ \\
\hline Fisabilillah & $13,171,568,353.00$ & Gharimin & $13,312,500.00$ \\
\hline Gharimin & $13,312,500.00$ & Ibnu Sabil & $4,483,800.00$ \\
\hline Ibnu Sabil & $4,483,800.00$ & Muallaf & $8,000,000.00$ \\
\hline Muallaf & $8,000,000.00$ & Fisabilillah & $32,461,804,023.00$ \\
\hline Dana bergulir & $3,632,907,597.00$ & Amil & $9,440,497,506.00$ \\
\hline Penyaluran kepada dana pengelola & $9,440,497,508.00$ & Jumlah Penyaluran & $80,116,314,630.00$ \\
\hline Penyaluran kepada dana lain & $18,430,664,390.00$ & Surplus & $(3,072,429,281.00)$ \\
\hline Pembelian aktiva tetap & $1,712,435,709.00$ & Transfer Antar Dana & - \\
\hline Pengeluaran lain-lain & $770,033,431.00$ & Saldo dana awal & $46,036,122,879.00$ \\
\hline Pemberian piutang hutang & $379,994,710.00$ & Saldo dana akhir & $42,963,693,598.00$ \\
\hline Jumlah Penggunaan Dana & $85,752,114,799.00$ & & \\
\hline Surplus/Defisit & $(4,443,392,920.00)$ & & \\
\hline \multicolumn{4}{|l|}{ Transfer antar dana: } \\
\hline Transfer dana dari/kepada dana lain & - & & \\
\hline Saldo awal & $28,018,277,390.00$ & & \\
\hline Saldo akhir & $23,574,884,470.00$ & & \\
\hline
\end{tabular}

Sumber: Laporan Keuangan Yayasan Dompet Dhuafa Republika 2012, diolah oleh penulis

Sebelum laporan 2011 disesuaikan dengan PSAK 109 laporan perubahan dana dinamakan laporan sumber dan penggunaan dana. Terdapat selisih Rp 4.264.836.530 pada sisi penerimaan yang berasal dari pengembalian dana bergulir
Rp3.392.941.750 dan penerimaan lainlain Rp15.720.062. Penyesuaian fisabilillah sesudah PSAK 109 dilakukan dari jumlah Rp13.171.568.353 menjadi Rp32.461.804.023, jumlah tersebut berasal dari fisabilillah, penyaluran 
kepada dana lain dan pemberian hutang piutang. Selisih saldo awal sebelum menggunakan PSAK 109 Rp18.017.845.489 sedangkan selisih saldo akhir karena berbagai penyesuaian sejumlah Rp19.388.809.128.
Perubahan atas penerapan PSAK 109 terhadap laporan perubahan dana infak/sedekah dijelaskan sebagai berikut:

Tabel 4.3.: Perubahan Format Laporan Perubahan Dana Infak/Sedekah Laporan Sumber dan Penggunaan Dana Laporan Perubahan Dana

\begin{tabular}{lrlr}
\hline Dana Infak & \multicolumn{3}{l}{ Dana Infak } \\
\hline Penerimaan & \multicolumn{4}{l}{ Penerimaan } \\
\hline Penerimaaan Infak/sedekah & $14,762,598,052.00$ & Penerimaaan Infak & $14,762,598,052.00$ \\
\hline Penarikan dana bergulir dan investasi & $142,000,000.00$ & Penerimaan bagi hasil & $68,590,799.00$ \\
\hline Penerimaan bagi hasil & $68,590,799.00$ & Penerimaan lain-lain & $88,766,720.00$ \\
\hline Penerimaan dana pembiayaan & - & Jumlah Penerimaan dana & $14,919,955,571.00$ \\
\hline Penerimaan piutang/hutang & $887,191,897.00$ & \\
\hline Penyaluran dari dana lain & - & & \\
\hline Penerimaan lain-lain & $61,566,720.00$ & & \\
\hline Jumlah Penerimaan Dana & $15,921,947,468.00$ & & \\
\hline & & & \\
\hline Penggunaan Dana & & Program pendidikan & \\
\hline Sosialisasi Zakat, Infak/Sedekah dan & & & $429,114,400.00$ \\
Wakaf (ZISWAF) & & & \\
\hline Kegiatan sosial & $12,253,233,355.00$ & Program kesehatan & \\
\hline Kegiatan ekonomi & $1,622,370,622.00$ & Program sosial masyarakat & $3,885,085,553.00$ \\
\hline Kegiatan pendidikan & $18,339,000.00$ & Program ekonomi & $18,339,000.00$ \\
\hline Pembelian aset tetap & $429,114,400.00$ & Program kemanusiaan & $53,317,000.00$ \\
\hline Pemberian piutang/pembayaran hutang & $136,908,500.00$ & Program advokasi & $7,500,000.00$ \\
\hline Penyaluran kepada dana lain & $637,985,721.00$ & Pengembangan jaringan & $632,565,262.00$ \\
\hline Biaya dibayar dimuka & $164,593,667.00$ & Jumlah Penyaluran & $5,025,921,215.00$ \\
\hline Pengeluaran lain-lain & $128,341,100.00$ & Fundraising & - \\
\hline Jumlah Penggunaan Dana & $724,500.00$ & Operasional kantor & \\
\hline Surplus/Defisit & $15,391,610,865.00$ & Jumlah Penyaluran & $5,025,921,215.00$ \\
\hline Transfer antar dana: & $530,336,603.00$ & Surplus & $9,894,034,356.00$ \\
\hline Transfer dana dari/kepada dana lain & $(801,241,531.00)$ & Transfer Antar Dana & $(10,372,841,840.00)$ \\
\hline Saldo awal & $1,829,500,320.00$ & Saldo dana awal & $577,881,442.00$ \\
\hline Saldo akhir & $1,558,595,392.00$ & Saldo dana akhir & $99,073,958.00$
\end{tabular}

Sumber: Laporan Keuangan Yayasan Dompet Dhuafa Republika 2012, diolah oleh penulis

Penyesuaian dilakukan terhadap pencatatan penerimaan dana bergulir dan penerimaan hutang/piutang serta penerimaan lain-lain sebesar Rp27.200.000 sehingga berpengaruh terhadap berkurangnya jumlah penerimaan infak Rp1.001.991.897.

Perubahan perlakuan akuntansi dilakukan pada sisi pengeluaran dengan menghapuskan sosialisasi zakat dan infak/sedekah, penyaluran pada dana lain, biaya dibayar dimuka serta 
penerimaan lain-lain. Pencatatan setelah PSAK 109 menitikberatkan pada program-program yang mencerminkan pemanfaatan dana infak/sedekah. Selisih akibat perubahan pencatatan sebesar Rp10.365.689.650., kemudian disesuaikan dalam transfer antar dana
Rp10.372.841.840. Selisih saldo dana infak/sedekah awal dan akhir tahun masing-masing sebesar Rp1.251.618.878 dan Rp1.459.521.434.

Perbedaan pencatatan pada laporan perubahan infak/sedekah terikat dijabarkan dalam tabel dibawah ini:

Tabel 4.4.: Perubahan Format Laporan Perubahan Dana Infak/Sedekah

\begin{tabular}{|c|c|c|c|}
\hline Dana Infak terikat & & Dana Infak terikat & \\
\hline Penerimaan & & Penerimaan & \\
\hline Penerimaan dana infak terikat & $32,387,817,921.00$ & Penerimaan Infak Terikat & $32,387,817,921.00$ \\
\hline Penerimaan bagi hasil & $323,730,446.00$ & Penerimaan bagi hasil & $323,730,446.00$ \\
\hline Penerimaan pelunasan piutang & $1,418,583,771.00$ & Penerimaan lain-lain & $117,720,852.00$ \\
\hline Penerimaan dana pembiayaan & $5,873,067,500.00$ & Jumlah Penerimaan dana & $32,829,269,219.00$ \\
\hline Penerimaan lain-lain & $117,720,852.00$ & & \\
\hline Jumlah Penerimaan dana & $40,120,920,490.00$ & Penyaluran & \\
\hline & & Program Pendidikan & $17,324,110,701.00$ \\
\hline Penggunaan Dana & & Program kesehatan & $1,025,172,848.00$ \\
\hline Penyaluran dana infak terikat & $27,374,902,893.00$ & Program sosial masyarakat & $7,659,930,323.00$ \\
\hline Investasi & $692,129,750.00$ & Program ekonomi & $1,365,689,022.00$ \\
\hline Penyaluran kepada dana lain & $579,675,611.00$ & Program kemanusiaan & - \\
\hline Pembelian aset tetap & $399,986,684.00$ & Program advokasi & - \\
\hline $\begin{array}{l}\text { Pemberian piutang/pembayaran } \\
\text { hutang }\end{array}$ & $6,306,748,200.00$ & Jumlah Penyaluran & $27,374,902,894.00$ \\
\hline Pengeluaran lain-lain & $3,548,583,911.00$ & Fundraising & $3,515,805,473.00$ \\
\hline Jumlah Penggunaan Dana & $38,902,027,049.00$ & Operasional kantor & - \\
\hline & & Jumlah Penyaluran & $30,890,708,367.00$ \\
\hline Surplus & $1,218,893,441.00$ & Surplus & $1,938,560,852.00$ \\
\hline Transfer Antar Dana & $(911,337,821.00)$ & Transfer Antar Dana & $(579,675,611.00)$ \\
\hline Saldo dana awal & $7,972,303,240.00$ & Saldo dana awal & $14,406,405,508.00$ \\
\hline Saldo dana akhir & $8,279,858,860.00$ & Saldo dana akhir & $15,765,290,749.00$ \\
\hline
\end{tabular}

Sumber: Laporan Keuangan Yayasan Dompet Dhuafa Republika 2012, diolah oleh penulis

Laporan setelah penerapan PSAK mencatat selisih penerimaan sebesar Rp7.291.651.271 yang berasal dari pelunasan piutang dan penerimaan dana pembiayaan. Seperti laporan perubahan dana infak/sedekah, penyesuaian dalam berbagai program penyaluran infak/sedekah terikat dilakukan sehingga memunculkan selisih Rp Rp8.011.318.632, dengan menghapuskan account investasi, penyaluran pada dana lain, pembelian asset tetap, pembayaran hutang/piutang serta pengeluaran lain-lain. Penyesuaian terhadap saldo awal dan saldo akhir sebesar Rp6.434.102.268 dan Rp7.485.431.889 karena perubahan perlakuan akuntansi.

Laporan perubahan dana diperbandingkan setelah penerapan PSAK 109 selengkapnya tersaji dalam tabel:

Tabel 4.5.: Laporan Penggunaan Dana 


\begin{tabular}{lrrr}
\hline DANA ZAKAT & & & \\
\hline Penerimaan & & & \\
\hline Penerimaan zakat & $75,523,980,061.00$ & $98,273,159,424.00$ & $124,333,855,931.00$ \\
\hline Penerimaan bagi hasil & $600,163,230.00$ & $657,372,638.00$ & $1,038,593,261.00$ \\
\hline Penerimaan lain-lain & $919,742,058.00$ & $83,581,011.00$ & $335,127,881.00$ \\
\hline Jumlah Penerimaan Dana Zakat & $77,043,885,349.00$ & $99,014,113,073.00$ & $125,707,577,073.00$ \\
\hline Penyaluran & & & \\
\hline Fakir Miskin & $38,188,216,801.00$ & $42,746,717,855.00$ & $60,492,588,778.00$ \\
\hline Gharimin & $13,312,500.00$ & $627,912,760.00$ & $771,346,000.00$ \\
\hline Ibnu Sabil & $4,483,800.00$ & $67,920,700.00$ & $135,294,922.00$ \\
\hline Muallaf & $8,000,000.00$ & $23,750,000.00$ & $24,020,495.00$ \\
\hline Fisabilillah & $32,461,804,023.00$ & $30,344,860,266.00$ & $32,941,420,999.00$ \\
\hline Amil & $9,440,497,506.00$ & $12,090,701,059.00$ & $15,466,037,317.00$ \\
\hline Jumlah Penyaluran & $80,116,314,630.00$ & $85,901,862,640.00$ & $109,830,708,511.00$ \\
\hline Surplus & $(3,072,429,281.00)$ & $13,112,250,433.00$ & $15,876,868,562.00$ \\
\hline Transfer Antar Dana & - & & - \\
\hline Saldo dana awal & $46,036,122,879.00$ & $42,963,693,596.00$ & $56,075,011,843.00$ \\
\hline Saldo dana akhir & $42,963,693,598.00$ & $56,075,944,029.00$ & $78,025,824,434.00$ \\
\hline
\end{tabular}

\begin{tabular}{lrrr}
\hline DANA INFAK & & & \\
\hline Penerimaan & & & \\
\hline Penerimaaan Infak & $14,762,598,052.00$ & $29,284,121,186.00$ & $39,690,712,055.00$ \\
\hline Penerimaan bagi hasil & $68,590,799.00$ & $308,928,547.00$ & $31,568,658.00$ \\
\hline Penerimaan lain-lain & $88,766,720.00$ & $441,015,791.00$ & $900,272,693.00$ \\
\hline Jumlah Penerimaan dana Infak & $14,919,955,571.00$ & $30,034,065,524.00$ & $40,622,553,406.00$ \\
\hline Penyaluran & & & \\
\hline Program pendidikan & $429,114,400.00$ & $922,142,004.00$ & $1,762,261,804.00$ \\
\hline Program kesehatan & - & $1,704,102,324.00$ & $2,314,340,849.00$ \\
\hline Program sosial masyarakat & $3,885,085,553.00$ & $1,333,380,440.00$ & $5,845,338,785.00$ \\
\hline Program ekonomi & $18,339,000.00$ & $1,960,134,601.00$ & $248,936,382.00$ \\
\hline Program kemanusiaan & $53,317,000.00$ & $139,976,614.00$ & $287,061,500.00$ \\
\hline Program advokasi & $7,500,000.00$ & $472,001,600.00$ & $978,863,701.00$ \\
\hline Pengembangan jaringan & $632,565,262.00$ & & - \\
\hline Jumlah Penyaluran & $5,025,921,215.00$ & $6,531,737,583.00$ & $11,458,058,121.00$ \\
\hline Fundraising & - & $448,050,089.00$ & \\
\hline Operasional kantor & - & $350,859,635.00$ & \\
\hline Jumlah Penyaluran & $5,025,921,215.00$ & $7,330,647,307.00$ & $11,458,058,121.00$ \\
\hline Surplus & $9,894,034,356.00$ & $22,703,418,217.00$ & $29,164,495,285.00$ \\
\hline Transfer Antar Dana & $(10,372,841,840.00)$ & $(17,089,137,220.00$ & $(27,927,202,695.00)$ \\
& & & \\
\hline Saldo dana awal & $577,881,442.00$ & $99,073,959.00$ & $5,713,354,956.00$ \\
\hline Saldo dana akhir & $99,073,958.00$ & $5,713,354,956.00$ & $6,950,647,546.00$ \\
\hline
\end{tabular}


Sumber: Laporan Keuangan Yayasan Dompet Dhuafa Republika 2011/2012, diolah oleh penulis

4.2 Pemenuhan Aspek Transparansi

Laporan keuangan yang disajikan oleh Yayasan Dompet Dhuafa Republika periode 2010, 2011, 2012, 2013 secara lengkap tersaji dalam website dompetdhuafa.or.id dan dapat diakses serta diunduh secara bebas oleh masyarakat. Secara periodik laporan tersebut diaudit oleh kantor akuntan publik sehingga secara format maupun konten memenuhi standar pencatatan yang ditetapkan. Sesuai PSAK 109 laporan terdiri dari laporan posisi keuangan, laporan perubahan dana, laporan perubahan asset kelolaan, laporan arus kas serta catatan laporan keuangan.

\subsubsection{Analisis Input-Output}

Analisis efisiensi yang membandingkan penerimaan dengan total penyaluran dan saldo dana dapat digunakan untuk menilai dan mengukur akuntabilitas (pertanggungjawaban) lembaga pengelola zakat. Total dana zakat dan infak tersedia untuk disalurkan merupakan penjumlahan dana zakat terkumpul pada tahun berjalan dengan saldo dana yang berasal dari tahun sebelumnya. Rasio penyaluran merupakan persentase total penyaluran dibandingkan dengan dana tersedia untuk disalurkan. Rasio tersebut mengukur pemanfaatan dana kepada mustahik. Rasio saldo dana diperhitungkan dari saldo dana dibandingkan dengan dana tersedia untuk disalurkan, yang mengindikasikan jumlah dana yang belum termanfaatkan pada tahun berjalan. Rasio pemanfaatan dan saldo dana dijelaskan dalam tabel 5.6.

Tabel 5.6.: Rasio Penyaluran dan Saldo Dana

\begin{tabular}{|c|c|c|c|}
\hline & 2011 & 2012 & 2013 \\
\hline \multicolumn{4}{|l|}{ Dana Zakat } \\
\hline Saldo Dana Zakat Awal & $46,036,122,879.00$ & $42,963,693,596.00$ & $56,075,944,029.00$ \\
\hline Penerimaan Zakat & $77,043,885,349.00$ & $99,014,113,073.00$ & $125,707,577,073.00$ \\
\hline Transfer antar Dana & - & - & $6,073,011,843.00$ \\
\hline $\begin{array}{l}\text { Dana Zakat } \text { Tersedia untuk } \\
\text { Disalurkan }\end{array}$ & $123,080,008,228.00$ & $141,977,806,669.00$ & $187,856,532,945.00$ \\
\hline Penyaluran Zakat & $80,116,314,630.00$ & $85,901,862,640.00$ & $109,830,708,511.00$ \\
\hline Saldo Dana Zakat Akhir & $42,963,693,598.00$ & $56,075,944,029.00$ & $78,025,824,434.00$ \\
\hline Rasio Penyaluran Dana Zakat & $65 \%$ & $61 \%$ & $58 \%$ \\
\hline Rasio Saldo Dana Zakat & $35 \%$ & $39 \%$ & $42 \%$ \\
\hline \multicolumn{4}{|l|}{ Dana Infak } \\
\hline Saldo Dana Infak Awal & $577,881,442.00$ & $99,073,959.00$ & $5,713,354,956.00$ \\
\hline Penerimaan dana Infak & $14,919,955,571.00$ & $30,034,065,524.00$ & $40,622,553,406.00$ \\
\hline Transfer antar Dana & $(10,372,841,840.00)$ & $(17,089,137,220.00)$ & $(27,927,202,695.00)$ \\
\hline $\begin{array}{l}\text { Dana Infak Tersedia untuk } \\
\text { Disalurkan }\end{array}$ & $5,124,995,173.00$ & $13,044,002,263.00$ & $18,408,705,667.00$ \\
\hline Penyaluran Infak & $5,025,921,215.00$ & $7,330,647,307.00$ & $11,458,058,121.00$ \\
\hline
\end{tabular}




\begin{tabular}{|c|c|c|c|}
\hline Saldo Dana Infak Akhir & $99,073,958.00$ & $5,713,354,956.00$ & $6,950,647,546.00$ \\
\hline Rasio Penyaluran Dana Infak & $98 \%$ & $56 \%$ & $62 \%$ \\
\hline Rasio Saldo Dana Infak & $2 \%$ & $44 \%$ & $38 \%$ \\
\hline \multicolumn{4}{|l|}{ Dana Infak Terikat } \\
\hline Saldo Dana Infak Terikat Awal & $14,406,405,508.00$ & $15,765,290,749.00$ & $33,269,800,941.00$ \\
\hline Penerimaan dana Infak Terikat & $32,829,269,219.00$ & $48,496,416,298.00$ & $25,823,196,496.00$ \\
\hline Transfer antar Dana & $(579,675,611.00)$ & $4,617,387,525.00$ & $(551,440,780.00)$ \\
\hline $\begin{array}{l}\text { Dana Infak Terikat Tersedia } \\
\text { untuk Disalurkan }\end{array}$ & $46,655,999,116.00$ & $68,879,094,572.00$ & $58,541,556,657.00$ \\
\hline Penyaluran Infak Terikat & $30,890,708,367.00$ & $35,609,293,631.00$ & $33,493,926,827.00$ \\
\hline Saldo Dana Infak Terikat Akhir & $15,765,290,749.00$ & $33,269,800,941.00$ & $25,047,629,830.00$ \\
\hline Rasio Penyaluran Dana Infak & $66 \%$ & $52 \%$ & $57 \%$ \\
\hline Rasio Saldo Dana Infak & $34 \%$ & $48 \%$ & $43 \%$ \\
\hline
\end{tabular}

Sumber: Laporan Keuangan Yayasan Dompet Dhuafa Republika 2011/2012, diolah oleh penulis

PSAK 109 tidak mengatur jumlah minimum penyaluran dana zakat dan infak/sedekah. Dompet Dhuafa membuat kebijakan penyaluran setiap dana sesuai kaidah fiqh yang relevan dalam rencana kerja dan anggaran tahunan (RKAT) yang disusun oleh manajemen, disetujui dan disahkan oleh dewan pembina dan dewan syariah pada awal tahun. Besaran penyaluran setiap tahun berbeda sesuai dengan prioritas dalam rencana kerja. Selama tiga tahun berturut-turut rasio penyaluran dana zakat, infak dan infak terikat diatas 50\%. Fluktuasi tersebut dipengaruhi oleh penyaluran dalam bentuk program berkelanjutan, yang adakalanya berlanjut pada tahun pelaporan berikutnya.

\subsubsection{Persentase Penyaluran Dana}

.Proporsi penyaluran zakat kepada tiap mustahik diatur dengan kebijakan internal Dompet Dhuafa dalam bentuk penyaluran langsung maupun program. Dalam laporan 2011 persentase penyaluran kepada fakir miskin sebesar $48 \%$, fisabilillah $40 \%$, amil $12 \%$ dan asnaf lain masing-masing di bawah 1\%. Data selengkapnya tergambar dalam tabel berikut: 


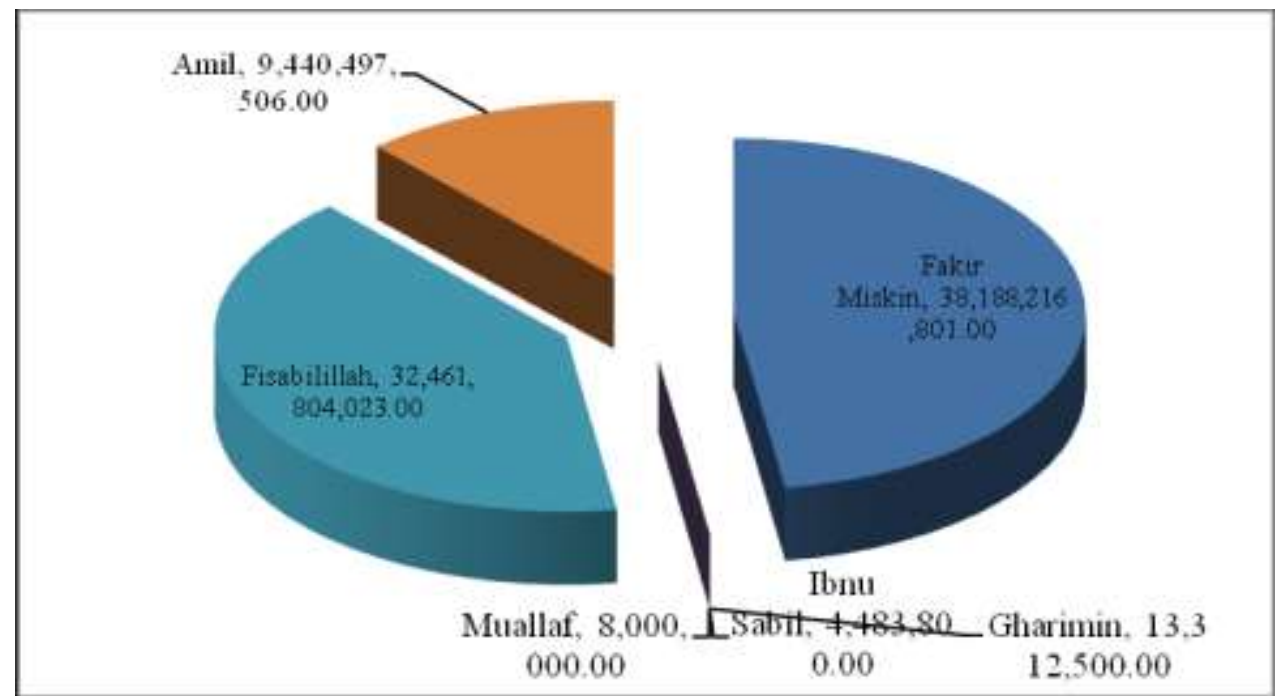

Gambar 5.1. : Persentase Penyaluran Zakat

Sumber: Laporan Keuangan Yayasan Dompet Dhuafa 2011, diolah oleh penulis

Peningkatan penyaluran pada tahun 2012 dan 2013 kepada fakir miskin, gharimin, ibnu sabil dan amil dengan persentase yang berbeda. Penurunan penyaluran terjadi pada asnaf fisabilillah dan mualaf. Perbandingan penyaluran dari tahun 2011 hingga 2013 selengkapnya terangkum dalam tabel berikut:

Tabel 5.7. : Penyaluran Dana Zakat

\begin{tabular}{lrrr}
\hline & $\mathbf{2 0 1 1}$ & $\mathbf{2 0 1 2}$ & $\mathbf{2 0 1 3}$ \\
\hline Penyaluran & & & \\
\hline Fakir Miskin & $47.67 \%$ & $49.76 \%$ & $55.08 \%$ \\
\hline Gharimin & $0.02 \%$ & $0.73 \%$ & $0.70 \%$ \\
\hline Ibnu Sabil & $0.01 \%$ & $0.08 \%$ & $0.12 \%$ \\
\hline Muallaf & $0.01 \%$ & $0.03 \%$ & $0.02 \%$ \\
\hline Fisabilillah & $40.52 \%$ & $35.33 \%$ & $29.99 \%$ \\
\hline Amil & $11.78 \%$ & $14.08 \%$ & $14.08 \%$ \\
\hline Jumlah & $100 \%$ & $100 \%$ & $100 \%$ \\
\hline Sumb
\end{tabular}

Sumber: Laporan Keuangan Yayasan Dompet Dhuafa

2011/2012, diolah oleh penulis

Penyaluran infak dan infak terikat dilakukan dalam bentuk program pemberdayaan dan peningkatan kapasitas masyarakat di bidang kesehatan, pendidikan, ekonomi, kemanusiaan, advokasi, sosial masyarakat. Data penyaluran dana infak dari periode 2011 hingga 2013 dijabarkan dalam tabel dibawah: 


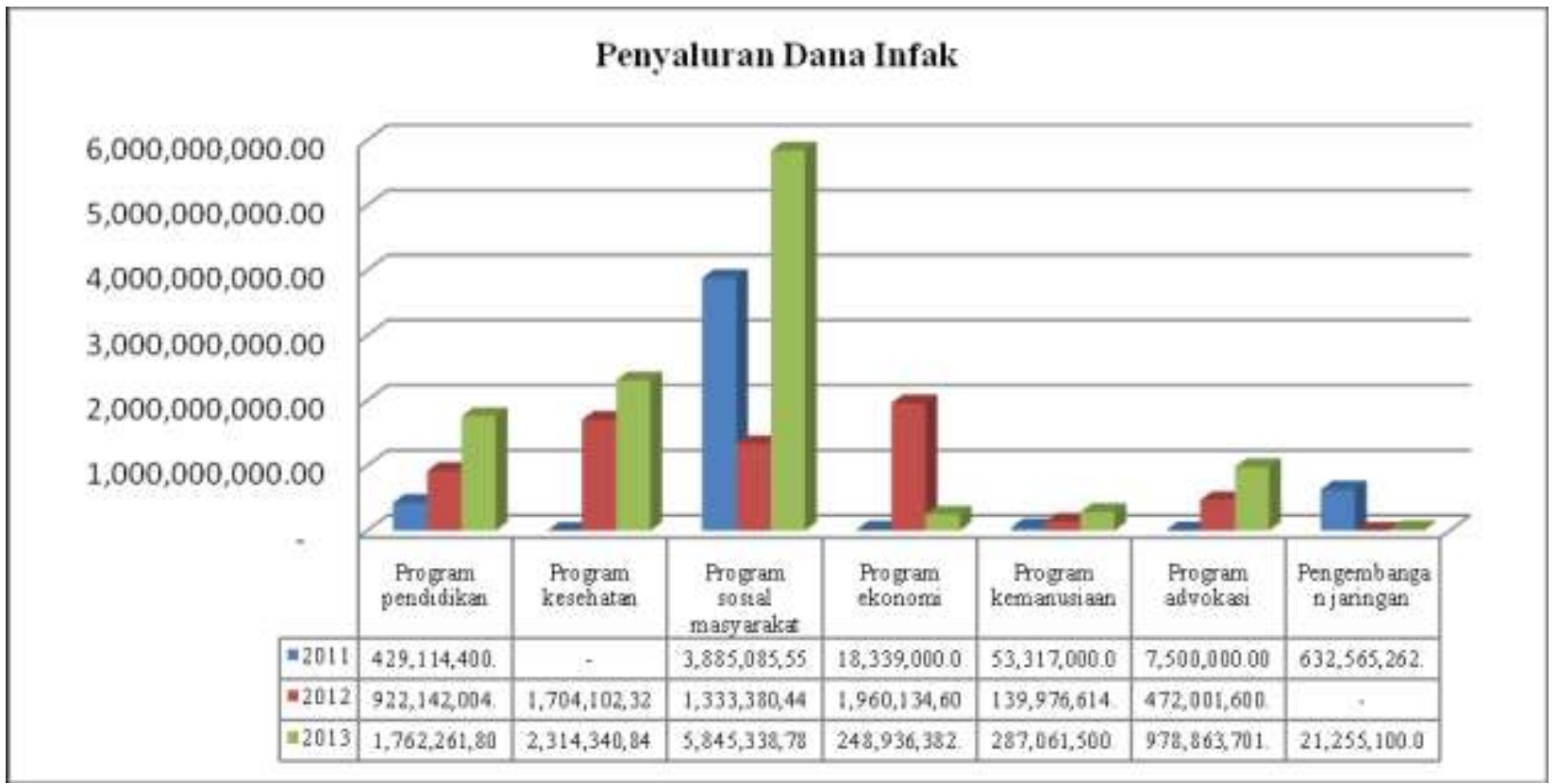

Gambar 5.2. : Persentase Penyaluran Dana Infak/Sedekah

Sumber: Laporan Keuangan Program ekonomi mengalami Yayasan Dompet Dhuafa 2011-2013, peningkatan pada tahun 2012, diolah oleh penulis sedangkan program advokasi terbesar

Rencana dan anggaran program terjadi pada tahun 2013. penyaluran dana infak/sedekah berbeda setiap tahunnya. Program sosial masyarakat menjadi prioritas penyaluran dari tahun 2011 hingga 2013 diikuti program kesehatan dan pendidikan.

\section{Penyaluran dana infak/sedakah terikat tersebar dalam beberapa program} sebagaimana dana infak/sedekah. Selengkapnya tersaji dalam gambar 5.3.

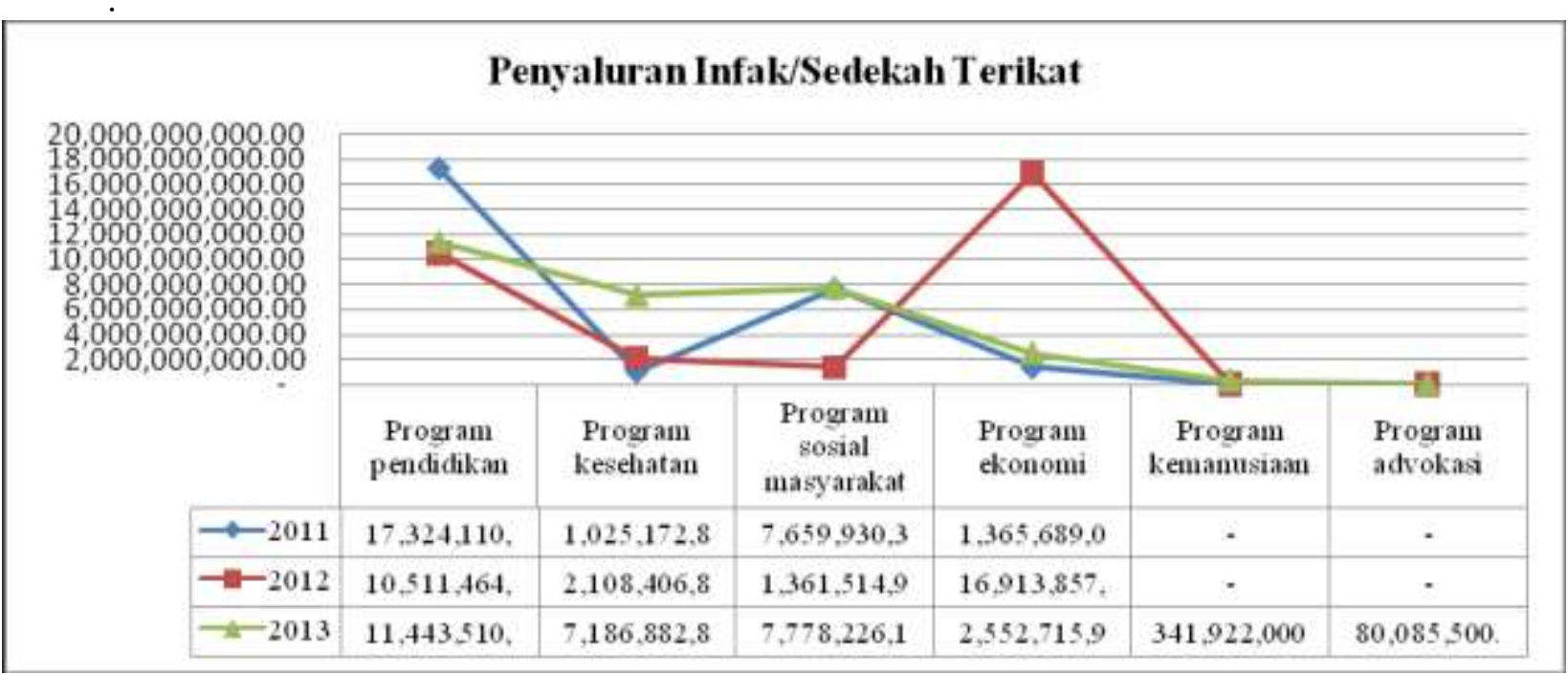

Gambar 5.3. : Persentase Penyaluran Dana Infak/Sedekah Terikat

Sumber: Laporan Keuangan Yayasan Dompet Dhuafa 2011-2013, diolah oleh penulis 
Pada tahun 2011 program pendidikan menempati prioritas tertinggi penyaluran dana infak/sedekah terikat diikuti dengan program sosial masyarakat, ekonomi dan kesehatan. Program ekonomi menyerap dana terbesar pada tahun 2012 dilanjutkan dengan program pendidikan, kesehatan dan sosial masyarakat. Pada 2013 persentase penyaluran terbesar untuk program pendidikan. Sesuai karakternya dana infak/sedekah terikat disalurkan sesuai dengan permintaan dan kesepakatan muzaki.

\subsubsection{Persentase Penerimaan Dana}

Salah satu indikator kinerja lembaga pengelola zakat adalah peningkatan kepercayaan publik yang tercermin dalam pertumbuhan penerimaan dana. Penerimaan zakat pada tahun 2012 dan 2013 masingmasing meningkat $29 \%$ dan $27 \%$ dari tahun sebelumnya. Penerimaan infak tahun 2012 mengalami lompatan yang cukup tajam sebesar $101 \%$ dan tumbuh $35 \%$ pada tahun 2013. Penerimaan infak terikat meningkat $48 \%$ pada 2012 , namun mengalami penurunan $47 \%$ pada tahun 2013. Gambaran penerimaan dana selengkapnya dalam tiga tahun berturutturut dijabarkan dalam tabel 5.7.

Tabel 5.8. : Rasio Peningkatan Penerimaan Dana

\begin{tabular}{cccc}
\hline & Penerimaan Zakat & Penerimaan Infak/Sedekah & $\begin{array}{c}\text { Penerimaan } \\
\text { Infak/Sedekah } \\
\text { Terikat }\end{array}$ \\
\hline $\mathbf{2 0 1 1}$ & $77,043,885,349.00$ & $14,919,955,571.00$ & $32,829,269,219.00$ \\
\hline $\mathbf{2 0 1 2}$ & $99,014,113,073.00$ & $30,034,065,524.00$ & $48,496,416,298.00$ \\
\hline $\mathbf{2 0 1 3}$ & $125,707,577,073.00$ & $40,622,553,406.00$ & $25,823,196,496.00$ \\
\hline & & & \\
\hline & & Peningkatan & $48 \%$ \\
\hline $\mathbf{2 0 1 2}$ & $29 \%$ & $101 \%$ & $-47 \%$ \\
\hline $\mathbf{2 0 1 3}$ & $27 \%$ & $35 \%$ & \\
\hline
\end{tabular}

Sumber: Laporan Keuangan Yayasan Dompet Dhuafa Republika 2011/2012,

diolah oleh penulis

\section{KESIMPULAN DAN REKOMENDASI}

\subsection{Kesimpulan}

Zakat dan infak/sedekah memiliki peran penting dalam tatanan sosial kemasyarakatan dan ekonomi dalam sebuah negara. Manfaat optimal akan dirasakan oleh mustahik, bilamana pengelolaan zakat dan infak/sedekah dilakukan secara terstruktur dalam program berkelanjutan oleh lembaga atau organisasi yang professional. Sebagai lembaga pengelola dana publik, organisasi pengelola zakat bertanggungjawab mengedepankan aspek keterbukaan dan kejujuran dalam memaksimalkan dana yang dikelola. Pelaporan keuangan sesuai dengan standar keuangan yang berlaku merepresentaikan keterbukaan yang dapat meningkatkan kepercayaan masyarakat. Beberapa hal dapat disimpulkan dalam pembahasan laporan keuangan Dompet Dhuafa:

1. Dompet Dhuafa selalu melalukan proses audit laporan keuangan setiap periode untuk memenuhi aspek akuntabilitas kepada masyarakat dan stakeholder lainnya.

2. Sebagai wujud keterbukaan dan transparansi, laporan yang telah diaudit tersebut dapat diakses 
dengan mudah dalam laman website dompetdhuafa.or.id.

3. Pengaruh PSAK 109 dalam laporan keuangan terlihat dalam penyajian laporan posisi keuangan yang lebih detil dan terinci baik disisi aset maupun liabilitas serta saldo dana. Perubahan signifikan terjadi dalam laporan perubahan dana yang menyebabkan dilakukannya adjustment terhadap pencatatan dan perlakuan akuntansi setiap jenis dana.

4. Dompet dhuafa memiliki kebijakan penyaluran dalam rencana kerja dan anggaran tahunan. Besaran penyaluran setiap jenis dana dalam tiga tahun berturut-turut rata-rata di atas 50\%. Saldo dana digunakan untuk kelangsungan program di tahun berikutnya.

5. Persentase terbesar penyaluran zakat diberikan kepada fakir miskin, sedangkan program sosial kemasyarakatan menjadi prioritas penyaluran infak.

6. Pertumbuhan penerimaan dana zakat dan infak/sedekah merupakan indikator positif peningkatan kepercayaan masyarakat kepada Dompet Dhuafa.

\subsection{Saran}

Berdasarkan pemaparan dan kesimpulan yang diberikan, penulis memberikan beberapa saran dan masukan:

1. Untuk memenuhi aspek keterbukaan dan pertanggungjawaban kepada masyarakat, laporan keuangan dapat dilengkapi dengan data-data kinerja organisasi yang berisi statistik penerimaan dan penyaluran dana, program yang dilaksanakan, dana penerima manfaat dan informasi lain yang relevan.

2. Laporan keuangan yang dipublikasikan di website perlu dilengkapi dengan pernyataan dewan syariah untuk menguatkan bahwa pengelolaan dana zakat dan infak/sedekah telah memenuhi aspek kepatuhan syariah.
3.Menyajikan kebijakan penyaluran secara umum untuk menguatkan pernyataan dewan syariah terkait penyaluran dana.

\section{Daftar Pustaka}

Yusuf al-Qaradawi. (2011). Hukum Zakat (Terjemahan).Cetakan 12. Jakarta (ID): Litera Antarnusa.

Ikatan Akuntansi Indonesia. (2010). Pernyataan Standar Akuntansi Keuangan, Akuntansi Zakat dan Infak/Sedekah. Jakarta (ID): Ikatan Akuntansi Indonesia.

Hisham Yaacob, and Hairul Suhaimi Nahar. Accounting and Accountability in The Sacred Context: The Case of A Malaysian Cash Awqaf Institution. Penang (MY).

Dr. Zahri Hamat. (2009). Zakat Accounting and Taxation in Malaysia. Penang (MY): Center for Islamic Development Management Studies.

Kustiawan Teten, dan Widodo Hertanto. (2001). Akuntansi dan Manajemen Keuangan untuk Organisasi Pengelola Zakat. Jakarta (ID): IMZ

Said H. Abdullah, Zainuri F. Zainal, Abdul Rasool S. Mohd. (2016). Zakat Kontemporerari: Perluasan Sumber dan Konsep Asnaf. Kuala Lumpur (MY): Attin Press Sdn. Bhd.

Kusuma A. Kumara. (2013). Mengembangkan Indikator Ekonomi Islam Melalui Zakat. Jakarta (ID): IMZ Publishing.

Ahmad Hj. Ismail, Jaafar Shamsuddin, Zakaria S. Sukman, Abdul Rahman J. Mohamad. (2013). Efisiensi Pengumpulan dan Distribusi Zakat oleh Lembaga 
Zakat Selangor. Jakarta (ID):

IMZ Publishing.

Hafhiduddin Didin, Tulus, Erman

Taufik, Abdullah Abdul Ghani, Djailani, Sudewo Eri,, suma A.

Muhammad, Mas'udi E.

Masdar, Widjoyo Seman,

Zulkarnain Iskandar, Yusanto I.

Muhammad. (2003).

Problematika Zakat

Kontemporer. Jakarta (ID):

Forum Zakat.

Hisyam Said M. (2014). CSR Guide. Jakarta (ID): IMZ Publishing.

Mufli Muhammad, Fariz Mohammad.

(2015). Sharia Traditional

Market Area: Revitalisasi Pasar

Tradisional Berbasis

Pemberdayaan Ekonomi Umat

Melalui Optimalisasi Potensi

Waqaf. Jakarta (ID).

http://sulut.kemenag.go.id/file/file/Bima sIslam/sqcl1400560110.pdf

http://yogyakarta1.kemenag.go.id/index. php?a $=$ artikel\&id $=28$

http://finance.detik.com/read/2011/12/16 /104258/1792590/4/ini-dia-20-

lembaga-penerima-zakat-yangdiakui-ditjen-pajak.

http ://www.blogspot/pengelolaan zakat melalui BAZ dan LAZ. Posted 2 Nopember 2008 http://www.pajak.go.id/content/ 122211-daftar-lembagakeagamaan-yang-disahkan.

http://ovy19.wordpress.com/2010/01/05/

sistem-transparansi-dan-

akuntabilitas-terhadap-

keuangan-negara/

http://manoegra.multiply.com/journal/ite

$\mathrm{m} / 7$

https://bps.co.id 
